\title{
The Effect of Gasoline-Bioethanol Blends to The Value of Fuel's Octane Number
}

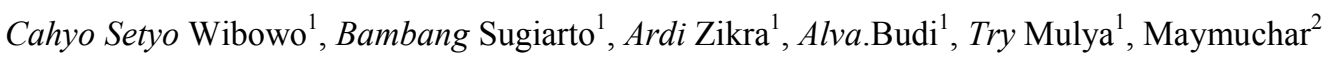 \\ E-mail : bangsugi@eng.ui.ac.id, cahyoswibowo@gmail.com \\ ${ }^{1}$ Department of Mechanical Engineering, Faculty of Engineering, Universitas Indonesia \\ ${ }^{2}$ Research and Development Centre for Oil and Gas Technology "LEMIGAS", Jakarta
}

\begin{abstract}
A fuel gasoline engine classified based is octane number, test for octane number using CFR engine with RON (Research Octane Number) ASTM D 2699 and MON (Motor Octane Number) ASTM D 2700. Bioethanol can booster octane number if blended to gasoline. A fuel to a higher octane can be run at a higher compression ratio without causing detonation or knocking engine. Compression is directly related to thermodynamic efficiency but to blended bioethanol can decrease the heating value of the fuel. The design engine on the market had compression ratio specified and needed octane number minimum specified. The experimental using CFR engine and using fuel gasoline in the market with blended bioethanol start from $5 \%-20 \%$ and analysis the relationship octane number after blended bioethanol with value compression ratio gasoline engine at the market. The objective of this research was the effect of blended bioethanol of varying gasoline forward octane number. The effect of blended bioethanol of gasoline between $5 \%-20 \%$ could increase to $11 \%$ of gasoline octane $88,2 \%$ of gasoline octane 98 . Keywords: research octane number (RON), motor octane number (MON), bioethanol, gasoline.
\end{abstract}

\section{Introduction}

Bioethanol can booster octane number if blended to gasoline. A fuel to a higher octane can be run at a higher compression ratio without causing detonation or knocking engine. Compression is directly related to thermodynamic efficiency but to blended bioethanol can decrease the heating value of the fuel. The design engine on the market had compression ratio specified and needed octane number minimum specified. The development technology engine for vehicle and motorcycle heading towards increasing compression ratio (CR) for optimum performance and improved engine thermal efficiency SI engine. The blended ethanol can reduce of engine knocking tendency[1-3].

The effectiveness increasing octane number with blended bioethanol to vary gasoline would to determine percentage bioethanol blend. As a biofuel, bioethanol can be used as a fuel substitution for gasoline. Bioethanol is a natural product and manufactured by the fermentation of plants containing sugar and starch. Characteristic physical and chemical of bioethanol near to gasoline. Using bioethanol-gasoline blended fuel can ease off the air pollution [4]. Increase ethanol content can increase the octane number, but decrease heating value [5]. Octane number is important parameter test for an effect to combustion, to decrease the octane number of combustion SI Engine can occur knocking. Two methods for measure octane number with research octane number and motor octane number of CFR engine $[6,8]$. The experimental test was using gasoline varying with octane number $88,92,98$, and $5 \%, 10 \%, 15 \%, 20 \%$ bioethanol blends from the market in Indonesia.

Hence, the current work aims at presenting the result on the effect of different percentages of bioethanol blends with 3 types of gasoline fuel on the value of fuel's octane number that would be useful for preventing knocking on the engine.

\section{Materials and Methods}

This experiments used fuels of bioethanol and three kind gasoline from the market in Indonesia.

Table 1. The basic value of octane number on fuels

\begin{tabular}{lccccc}
\hline Characteristics & Unit & $\mathbf{E 1 0 0}$ & $\mathbf{8 8}$ & $\mathbf{9 2}$ & $\mathbf{9 8}$ \\
\hline $\begin{array}{l}\text { Research } \\
\text { Octane Number } \\
\text { (RON) }\end{array}$ & 118 & 88 & 91.7 & 98 \\
\hline $\begin{array}{l}\text { Motor Octane } \\
\text { Number } \\
\text { (MON) }\end{array}$ & 100 & 73.5 & 78.6 & 83.4 \\
\hline Density $\left(\mathbf{1 5}^{\circ} \mathbf{C}\right)$ & $\mathrm{kg} / \mathrm{m}^{3}$ & 793.9 & 732 & 727.5 & 747.1 \\
\hline
\end{tabular}

The three type of gasoline blended with various percentages bioethanol $(5 \%, 10 \%, 15 \%$ and $20 \%)$ is

Corresponding author: bangsugi@eng.ui.ac.id 
testing with CFR Engine or commonly called Knocking Engine. The Waukesha CFR F1/F2 Combination Rating Unit is the globally accepted standard for determining and certifying the anti-knock characteristics of motor fuels. The F1/F2 unit can run both the Research Method (RON) and Motor Method (MON) test, with testing capabilities in the 40-120 octane number range.

At the heart of the CFR engine lies the variable compression cylinder and sleeve assembly by which the knock characteristics of unknown fuels can be determined. Varying the compression ratio by manipulating the cylinder height during engine operation produces various levels of knock intensity, making it possible to compare unknown fuels to reference fuels with known octane values. Cylinder height is correlated to a compression ratio which can then be directly correlated to a specific octane value as per ASTM method specifications $[6,8]$.

\section{Results and Discussion}

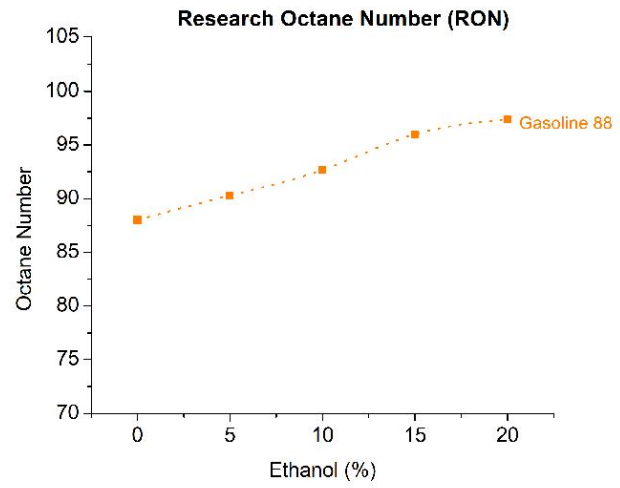

Fig. 1. Gasoline 88 Research Octane Number vs Percentages of Bioethanol Added

The figure 1 appeared blended bioethanol from $0 \%, 5 \%$, $10 \%, 15 \%, 20 \%$ of gasoline 88 can increase value research octane number namely: $0 \%, 3 \%, 5 \%, 9 \%, 11 \%$. The effect of blended bioethanol with gasoline will more significance for characteristic octane number if the base gasoline had lower octane number.

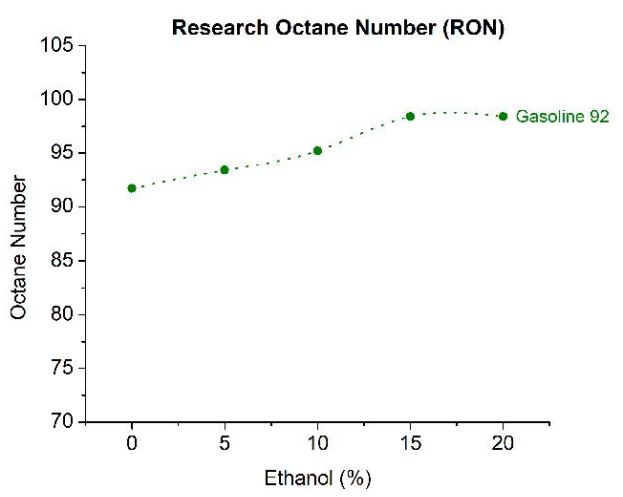

Fig. 2. Gasoline 92 Research Octane Number vs Percentages of Bioethanol Added
The figure 2 appeared blended bioethanol from $0 \%$, $5 \%, 10 \%, 15 \%, 20 \%$ of gasoline 92 can increase value research octane number namely: $0 \%, 2 \%, 4 \%, 7 \%, 7 \%$.

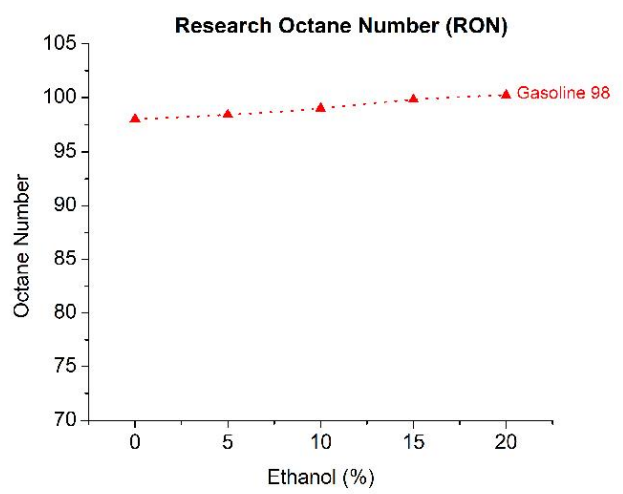

Fig 3. Gasoline 98 Research Octane Number vs Percentages of Bioethanol Added

The figure 3 appeared blended bioethanol from $0 \%$, $5 \%, 10 \%, 15 \%, 20 \%$ of gasoline 98 can increase value research octane number namely: $0 \%, 0,4 \%, 1 \%, 2 \%, 2 \%$.

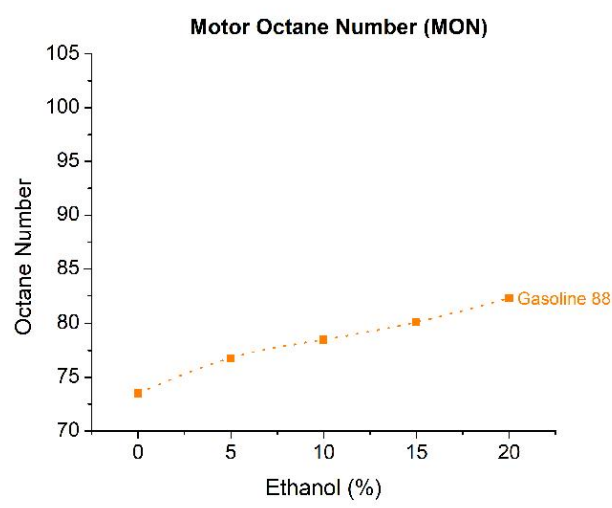

Fig. 4. Gasoline 88 Motor Octane Number vs Percentages of Bioethanol Added

The figure 4 appeared blended bioethanol from $0 \%$, $5 \%, 10 \%, 15 \%, 20 \%$ of gasoline 88 can increase value motor octane number namely: $0 \%, 0,4 \%, 7 \%, 9 \%, 12 \%$.

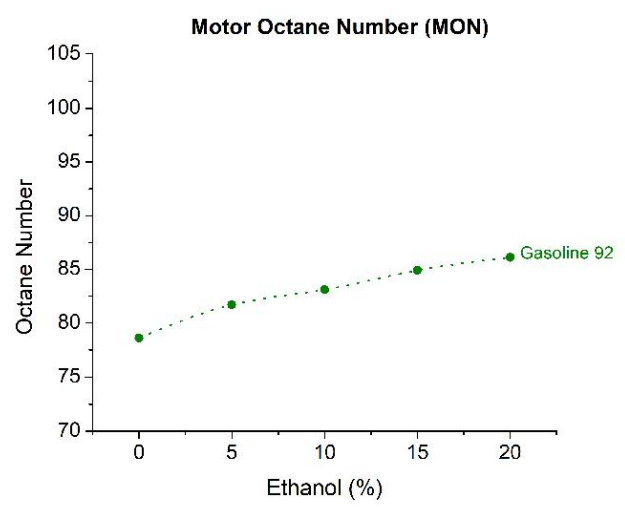

Fig. 5. Gasoline 92 Motor Octane Number vs Percentages of Bioethanol Added

Corresponding author: bangsugi@eng.ui.ac.id 
The figure 5 appeared blended bioethanol from $0 \%$, $5 \%, 10 \%, 15 \%, 20 \%$ of gasoline 92 can increase value motor octane number namely: $0 \%, 4 \%, 6 \%, 8 \%, 10 \%$.

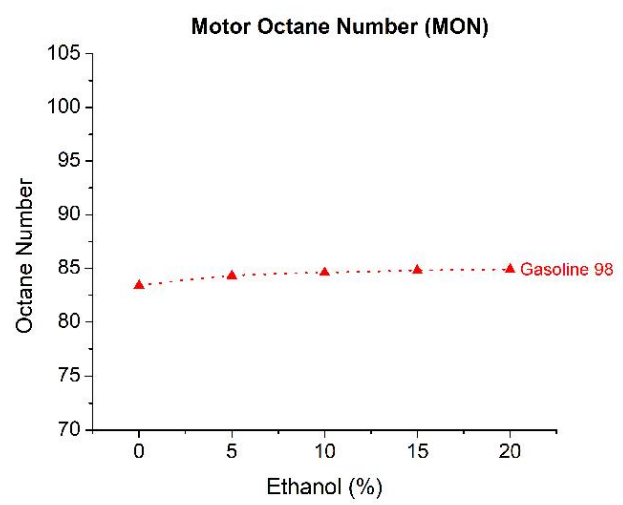

Fig. 6. Gasoline 98 Motor Octane Number vs Percentages of Bioethanol Added

The figure 6 appeared blended bioethanol from $0 \%$, $5 \%, 10 \%, 15 \%, 20 \%$ of gasoline 98 can increase value motor octane number namely: $0 \%, 1 \%, 1 \%, 2 \%, 2 \%$.

The ignition quality and flammability gasoline can measure with: Research Octane Number (RON) and Motor Octane Number (MON). Antiknock Index (AKI) is a measure of a resistant knocking, $(\mathrm{RON}+\mathrm{MON}) / 2$ [9].

Table 2. AKI (Anti Knocking Index) of fuels

\begin{tabular}{lccccc}
\hline Gasoline & E0 & E5 & E10 & E15 & E20 \\
\hline $\mathbf{9 8}$ & 90.7 & 91.4 & 91.8 & 92.3 & 92.6 \\
\hline $\mathbf{9 2}$ & 85.2 & 87.6 & 89.2 & 91.7 & 92.3 \\
\hline $\mathbf{8 8}$ & 80.8 & 83.6 & 85.6 & 88.1 & 89.9 \\
\hline
\end{tabular}

Table 2 shows the effective increase of the octane number value of fuel blended with bioethanol, the increase is evident in the three types of fuel used in this reasearch.

\section{Conclusion}

The effect of bioethanol blending on fuel showed an increase in the octane number values for all three fuels tested in this research. The significant increase occurred when using the gasoline 88 blended with $20 \%$ volume of bioethanol. The RON (Research Octane Number) value's is increased to $11 \%$, while the MON (Motor Octane Number) is increased to $12 \%$ of the previous value. The increase in octane value itself is due to the bioethanol's octane number which is higher than the octane number of gasoline.

The increase in octane number value is obviously also increased its AKI (Anti Knocking Index) values. This indicates that bioethanol should be able to help avoid knocking on the engine when added in the fuel.
This research was supported by PITTA grant on contract number :2393/UN2.R3.1/HKP.05.00/2018, Universitas Indonesia.

\section{References}

[1] Sakai S, Rothamer D. Physical and chemical properties of ethanol/gasoline blends and their effects on combustion in spark-ignition engines; 2015.

[2] West B. High octane ethanol blends for improved vehicle efficiency. Oak Ridge National Laboratory; 2015.

[3] Caton PA, Hamilton LJ, Cowart JS. An experimental and modelling investigation into the comparative knock and performance characteristics of E85, gasohol [E10] and regular unleaded gasoline [87 $(\mathrm{R}+\mathrm{M}) / 2]$. SAE international 2007-01-0473; 2007

[4] Ozcelik A, Aydogan H, Acaroglu M. 2015. A study of the effects of bioethanol-gasoline blends on vehicle emissions. J Clean Energy Technologies. $3(5)$.

[5] Kima H, Choia B. 2008. Effect of ethanol-diesel blend fuels on emission and particle size distribution in a common-rail direct injection diesel engine with warm-up catalytic converter. J Renewable Energy. 33:2222-2228.

[6] ASTM D 2699, Standard Test Method for Research Octane Number of Spark-Ignition Engine Fuel, 2012

[7] ASTM D 4052, Density and Relative Density of Liquids by Digital Density Meter, 2002

[8] ASTM D 2700, Standard Test Method for Motor Octane Number of Spark-Ignition Engine Fuel, 2012

[9] Ayhan Demirbas, M.A. balubaid, A.M.Basahel, M.H.Sheikh, Octane Rating of Gasoline and Octane Booster Additives, Petroleum Science and Technology, June 2015 